\title{
Framing of European integration in Ukrainian media discourse
}

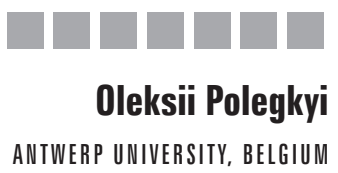

DOI: 10.19195/1899-5101.9.2(17).3

\begin{abstract}
The topic of European integration is one of the most important for Ukrainian political discourse and reflects the main controversy in politics and society. This paper is based on a case study: how are European integration and widely the idea of Europe conceptualized in Ukrainian political discourses and how are they presented and framed in the Ukrainian press in the period 2005-2010? What are the dominant frames in the representation of European integration in the Ukrainian press? This study demonstrates that conceptualization of European integration and, connected with it, the foreign policy choice of Ukraine is proceeding in the Ukrainian media discourse with usage of the following dominant frames: geopolitical confrontation, civilizational choice and an instrument of inner changes.
\end{abstract}

KEYWORDS: Ukrainian media, European integration, frame analysis, media discourse.

\section{INTRODUCTION}

The concept of EU integration became one of the essential elements for an understanding of Ukrainian political discourse and Ukrainian politics in general. Europe and Russia are the original poles of the debate on Ukrainian identity and foreign policy preferences. In terms of Laclau and Mouffe (1985), the different visions of Europe, and the geopolitical choice of Ukraine, according to it, are nodal points for Ukrainian discourses on identity. In this sense, Ukrainian identities are built by means of either referring to Europe or to other symbolic centers, like "Russian world".

Support for the idea of European integration amongst Ukrainians was uncertain in recent years. European integration has tended to be an elite-driven project across all post-communist countries and Ukraine is not an exception in that respect. But in contrast to CEE countries and Baltic States, Ukraine had no stable political support for Euro-Atlantic integration from the side of the European Union. Ukraine also faces an extremely difficult problem of building a stable pub- 
lic consensus on the strategy of European integration. Public opinion in general largely reflects the instability in Ukraine-EU relations, as well as the inconsistent European integration policy of the Ukrainian government and the lack of a coherent policy from the European Union.

To a large extent the level of support for each of the two main foreign policy directions depends on the political situation within the country. For example, we can see how the relations of Ukraine and the EU were seen by Ukrainians in the period 2005-2009 according to surveys by the Razumkov Centre. These attitudes are illustrated in Figure 1.

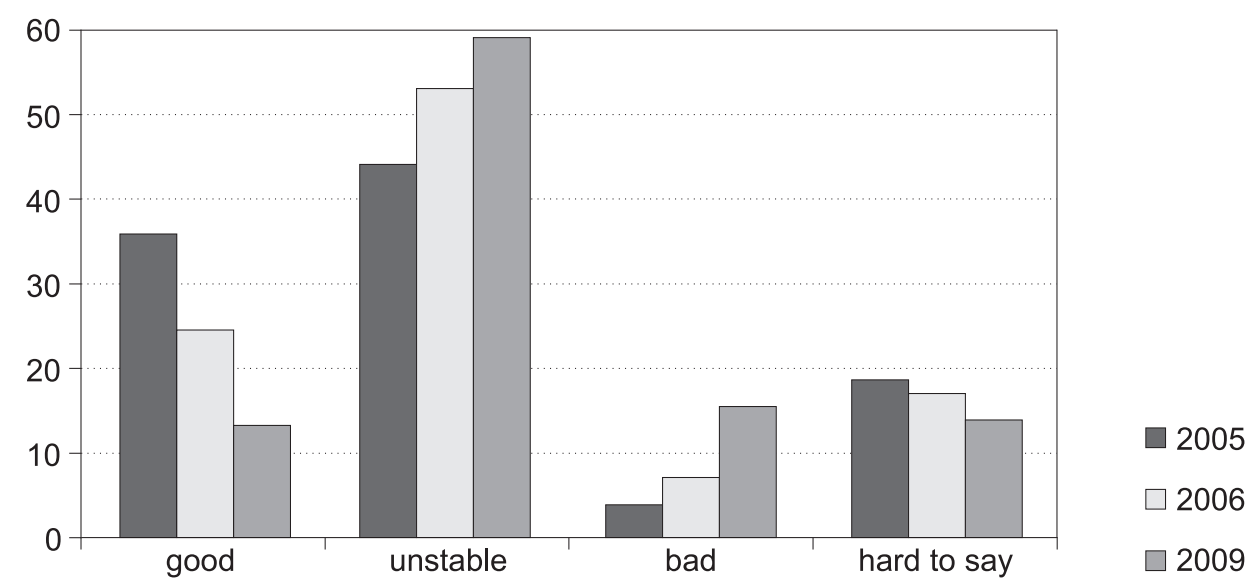

Figure 1. How would you describe the current relations of Ukraine and the EU? (in \%)

Source: Razumkov Centre (2010, p. 48).

Public opinion surveys show that Ukrainian citizens traditionally closely watch the development of their country's relations with its two main foreign partners: the EU and Russia. According to the Razumkov Center (Kapitonenko et al., 2012), from 2005 to 2010, relations with Russia were largely regarded as the main priority in foreign policy, but 2011 became the year of change. This trend was reversed as the Ukrainian public's attention and interest switched to the EU. According to the I. Kucheriv Democratic Initiatives Foundation (Zolkina, 2013), since 2011 public support for European integration has prevailed over support for integration into the Customs Union.

\section{THEORETICAL AND METHODOLOGICAL BACKGROUND}

Politics is a struggle over ideas and values, where not only social facts and events matter itself, but how they are interpreted and presented in public discourse. Both social and discourse practices frame, and in many ways define, the way individuals and groups present themselves to others, negotiate roles, and conceptualize them- 
selves (De Fina et al., 2006, p. 2). Van Dijk (2001, pp. 355-357) proposes a discursive definition of social power, because those who have more control and more influential discourse are also more powerful and "access to or control over public discourse and communication is an important 'symbolic' resource".

Framing theory suggests that the way media present certain information strongly influences the perception of events by readers. Frame analysis in media research derives from the assumption that media impact comes not only from the information brought to the audience, but also from the way the media organize and package this information. Frames attract our attention:

[...] to some aspects of reality while obscuring other elements, which might lead audiences to have different reactions. (Entman, 1993, p. 55)

Framing is the central process by which politicians and journalists exercise political influence over each other and over the public. Entman (2003, p. 417) insists that successful political communication requires the framing of issues, events, and actors in ways that promote perceptions and interpretations that benefit one side while hindering the other.

Entman suggests that framing plays an important role in the application of political power, especially if the audience is offered multiple frames. A particular political issue that is presented in multiple ways has a higher probability of influencing people on how they think about that issue. According to Entman (1993, p. 52), we can define framing as the process of selecting certain elements of reality and assembling a narrative that highlights connections among them to promote a particular interpretation. Framing is a process by which messages are structured in specific ways in order to influence the interpretation of the receiver. Media actively put the frames of reference which are used by the audience for an understanding and interpretation of facts and public events. Politicians engage in the struggle to determine how issues are framed, because via the procedure of "framing" we have the ability to modify the public's perception and reaction.

In the process of frame building, claims Van Gorp (2007), not only media make use of frames, but frames also influence the perception and schemas of the journalists in their covering of events.

There is interaction between the journalist's (un)conscious selection of a frame - out of the cultural stock of frames - as the result of the individual belief system, and the influence of additional factors inside and outside the media organizations. (Van Gorp, 2007, p. 67)

Here the analysis of framing in the Ukrainian press was drawn mainly from cognitive linguistics and media analysis. Cognitive linguistics sees a frame as the background knowledge "activated" by a particular concept. Frame knowledge is crucial to understanding the meaning of a word in its fullest sense. Media analysis extends this to say that facts make sense only when: 
[...] embedded in a frame or storyline that organizes them and gives them coherence, selecting certain ones to emphasize while ignoring others. (Gamson, 1989, p. 157)

The analytical part of this study was based on the ideas developed by Van Gorp (2007). Methodology of frame analysis includes two types of sources (or devices) - reasoning devices and framing devices. The first explains the event, while the second characterizes it. Selection and construction are basic procedures in framing according to Van Gorp. As a first step of analysis, frames "can be reconstructed on the basis of the framing devices in texts" such as "word choice, metaphors, exemplars, descriptions, arguments, and visual images" (Van Gorp, 2007, p. 64). Important for a frame package are "the reasoning devices that are demonstrably part of media content and discourse", which include "explicit and implicit statements that deal with justifications, causes, and consequences in a temporal order, and which complete the frame package" (Van Gorp, 2007, p. 64).

Van Gorp proposes to identify a frame matrix we can start with "the analysis of a strategically chosen set of media texts and determine for each text which elements and propositions can probably function as framing or reasoning devices". Afterwards, we can "identify logical chains of framing and reasoning devices across the separate texts". Then, keeping comparison with the previous finding, "the most representative devices can be identified and, finally, integrated in frame packages that are presented in a frame matrix" (Van Gorp, 2007, p. 72). However, since any frame analysis involves a significant part of interpretation, there is always a threat that the researcher will find the frames he consciously or subconsciously is looking for (Tankard, 2001). We can overcome it, supposes Van Gorp, by accepting that a series of manifest variables can represent a latent concept and by including multiple checking find representative devices.

The respective framing devices, transmuted in measurable variables, all refer to the frame as a latent meaning structure. It means, the causal statements (the reasoning devices) and the properties that together constitute the discursive domain of the media text (the framing devices) are identified. (Van Gorp, 2007, p. 70)

The time-frame for the selection of press material for analysis was limited to the period from 2005 till 2010. This period was taken because it provides the full range of the discussion on the topic of European integration in Ukraine. During that time the main positions and discourses were formed and presented in Ukrainian public discourse by major political and social groups. It was also the time when the main conceptual approach in internal and foreign policy was demonstrated by Ukrainian ruling elites. Overall, we intend to answer the following questions: How is European integration and the idea of Europe conceptualized in Ukrainian political discourses and how are they presented and framed in the Ukrainian press? What are the dominant frames in the representation of European integration in the Ukrainian press? 
We took the newspapers Zerkalo Nedeli, Fakty i Kommentarii (in short - Fakty) and Segodnia as a primary source of data for analysis. The newspapers differ from one another in their political orientation and/or targeted audience, which manifests itself in both the selection of topics and the manner of their presentation, despite the general claims of avoidance of overtly biased discourse. Fakty and Segodnia were selected as the biggest popular daily newspapers in Ukraine, which represent the popular press and which are widely circulating among different groups of Ukrainian society. According to Telekritika (2012), in 2011 the top two titles, relative to circulation and popularity, were the daily Segodnya and the newspaper Fakty. Among the socio-political weeklies, a high position was held by Zerkalo Nedeli.

The Zerkalo Nedeli was selected as an example of quality press because it is wellknown among Ukrainian politicians, experts and opinion makers. Zerkalo Nedeli is the largest and, probably, the most influential socio-political weekly newspaper in the country (BBC, 2006). Zerkalo Nedeli employs high journalistic standards and offers political and social analysis, exclusive interviews and different opinions and could be characterized as a qualitative one. This analytical weekly is published in Ukrainian and Russian.

Segodnia (BBC, 2006) was founded in 1997 as part of an effort by businessmen close to President Kuchma to provide popular media support for his regime. After the Orange Revolution in 2004, Segodnia became one of the editions controlled by the anti-Orange opposition. It was seen to be loyal to Viktor Yanukovych and welcomed his comeback as President after 2010. Segodnia is owned by the oligarch Rinat Akhmetov. It is primarily targeted at big cities which enable more effective distribution. Due to its political orientation and the use of the Russian language, it became particularly popular in the south-eastern part of the country and in the capital (Kulyk, 2011, p. 3).

The newspaper Fakty (BBC, 2006) belongs to the media-holding of Viktor Pinchuk, who is the son-in-law of former President Leonid Kuchma. Fakty is a popular Russian-language tabloid offering straight news and interviews, but little analysis, and was the biggest among popular editions in Ukraine by 2010 (Ivanov et al., 2011).

Fakty was the most popular newspaper in Ukraine in the 1990s-early 2000s, but later it was replaced by Segodnia. At the same time Fakty confirmed the Russian language not only as a norm, but also as the main language of Ukrainian mass newspapers, even bringing it to readers of the Western regions. Another feature of these newspapers was total loyalty to executive power, which confirmed its support of the authorities (Kulyk, 2010, p. 323).

For the research, the internet version of each newspaper was used. At the beginning, we took all of the articles from 2005 and 2010 from all three newspapers, which included any kind of relation to the following word combinations: Europe and European Union or EU and European integration or Eurointegration, or 
Ukraine-EU, Ukraine-European integration. The following search strategy was employed: the above mentioned terms - Europe etc. - had to be present in an article to be selected. We started with reading through all of the automatically retrieved data, then selected articles based on their relevance to the research topic, and later studied the texts for the analysis of the dominated frames. In the process of determining which articles to include or exclude, first we had to read them, at least briefly, then separate the selected articles into some groups (according to thematic area), marking them according to the topics they discussed or reported about. We selected articles which reflects any political, social, economic or cultural relevance to the topic of European integration. After completion of the first (exclusion) stage of the analysis, we continued with a more detailed analysis of the selected data set, and identification of the main framing devices. This search strategy resulted in the selection of 270 articles which were subjected to detailed analysis.

\section{MAIN FRAMES OF EUROPEAN INTEGRATION IN UKRAINIAN MEDIA DISCOURSE}

The conceptualization of European integration, and connected with it the foreign policy choice of Ukraine was found to be present in Ukrainian media discourse with the following frames:

- Geopolitical confrontation (in this frame, Ukraine is an instrument in the space of geopolitical confrontation between the USA, the EU and the Russian Federation);

- European integration - as a civilizational choice (concerning world-view and values);

- European integration - as an instrument of inner changes.

Meta-frame, in which the first two approaches are reflected, is a frame of the conflict: Europe (the West) against Russia (Table 1).

Table 1. Framing of European integration in Ukrainian Media Discourse and Main Conceptual Metaphors

\begin{tabular}{|c|c|c|c|}
\hline $\begin{array}{l}\text { Geopolitical } \\
\text { confrontation } \\
\text { Ukraine is an } \\
\text { instrument in the } \\
\text { space of geopolitical } \\
\text { confrontation between } \\
\text { the USA, the EU and } \\
\text { the RF } \\
\text { Ukraine as bridge/ } \\
\text { buffer }\end{array}$ & $\begin{array}{l}\text { Civilizational choice } \\
\text { Ukraine is an organic } \\
\text { part of Europe } \\
\text { European integration } \\
\text { is "returning home" }\end{array}$ & \multirow[t]{2}{*}{$\begin{array}{l}\text { Instrument of inner } \\
\text { changes } \\
\text { European integration } \\
\text { - as a chance for the } \\
\text { inner modernization } \\
\text { of Ukraine } \\
\\
\text { European integration } \\
\text { as chance/dream }\end{array}$} & \multirow[t]{2}{*}{$\begin{array}{l}\text { Negative frames } \\
\begin{array}{l}\text { Europe - as fortress/ } \\
\text { closed club }\end{array} \\
\text { Ukraine as a "dump" } \\
\text { of Europe, market of } \\
\text { low-grade products, } \\
\text { source of cheap } \\
\text { natural and labor } \\
\text { resources }\end{array}$} \\
\hline \multicolumn{2}{|c|}{$\begin{array}{l}\text { Conflict meta-frame: Europe (the West) } \\
\text { against Russia }\end{array}$} & & \\
\hline
\end{tabular}

Source: author. 
Without any doubt, there are other frames; moreover, all the frames mentioned above are mutually intersecting. But simplification and schematization of this kind, give us the opportunity to present different positions towards European integration that exist in the public discourse of Ukraine.

The most difficult to describe is the position of followers of a so-called "third" or independent way (neither towards Europe, neither to Russia). Very often this position is called the pragmatic one. To make things simple, we'll call them as followers of the pragmatic approach or of "non-alliance" of Ukraine to any unions. Its followers stand for pragmatism in the evaluation of the European perspectives of Ukraine and for the building of foreign policy of Ukraine, refusing "ideological" directives of confrontation between Europe and Russia. For example, that part of Yanukovych's team which regarded Russia as a threat to its own interests also tried to keep this pragmatic position in the relations with Russia.

The difficulty lies in the fact that this category includes groups which motivate the necessity of the third way for totally different reasons. Both nationalistically oriented groups, seeing Eurointegration as a threat to the independence of Ukraine (for example, some representatives of the nationalist party "Svoboda"), and "moderate" patriots, standing on rational bases, that the perspective of Ukraine's membership in the EU is not realistic, can be placed to this category. According to the views of such groups, as the EU itself is in crisis, Ukraine has to search for "its own" place in the world, not only oriented toward Europe or Russia, but looks at other regions as well.

\section{Frame of geopolitical confrontation}

In the frame of geopolitical confrontation the Euro-integrational aspirations of Ukraine are determined, first of all, by the relations between the EU and the USA with Russia. Ukraine performs here only as an instrument of a geopolitical struggle between world leaders and as an object of their foreign policy. The problem of Ukraine's geopolitical position revolves around the debate as to what civilization and part of the world Ukraine belongs to; "Ukraine is being torn between the spheres of influence of Moscow and the European Union" (Fakty, 2010c).

According to this frame, Ukraine is seen by both the West and Russia as a key battleground, not only over the country's geopolitical placement, but also between liberal and autocratic development in the entire post-Soviet region. As a result, both sides took an active role in ensuring that the outcome was in line with their values (Ambrosio, 2009).

In this frame, the myth of Europe versus Asia places a very clear boundary marker between Ukraine and Russia. In the geopolitical discourse, neighbors are viewed as borderline countries that constitute a buffer zone against the unfriendly "Big Other".

According to this frame, Russia cannot accept former Soviet republics as sovereign countries. Russia prefers not to view Ukraine as a truly independent country. The aim 
of Russian policy seems to be the maintenance of the political and economic dependence of Ukraine on Russia. At the same time, it would undermine Ukraine's integration with Western structures, which Russia sees as a threat to its interests.

Moreover, Russian political elites largely view the USA and EU presence in the Ukraine as a challenge to its security as it competes for Western influence. It is intent on preventing any state in Russia's "near abroad" from joining an alliance deemed hostile to Russia, primarily NATO.

As seen by the pro-European part of Ukrainian society, the European Union demonstrated a persistent lack of credibility with respect to Ukraine, preferring friendly relations with the Russian Federation and non-intervention into the sphere of Russian "privilege interests" in Ukraine.

In this frame the independence of Ukraine is tied directly to its release from Russian influence. Respectively, for pro-European followers Euro-integration means, first of all, strengthening the national security of Ukraine.

Only the total and quickest integration of Ukraine into the EU or, as a minimum - into the European economic area, could become at least some guarantee of security. (Hajdaj, 2010)

Followers of the total integration of Ukraine into the European Union come out from the fact, that by staying aside, Ukraine will have neither economic, nor political resources for foreign policy influence and it can turn sooner into a weak object, than into an active subject of European policy.

A possible alternative to European integration is a gradual marginalization of Ukraine, its economic underdevelopment, political instability and appearance of new threats to national security. Geopolitical uncertainness will make Ukraine too vulnerable to external pressure. [...] In this case the price of non-integration can be much higher than the price of integration. (Litvinenko, 2010)

The vision of Ukraine as a buffer zone between Russia and Europe or "the West" is a typically "geopolitical" view. Wherein, in Ukraine, supporters of Euro-integration are using such expressions as well as its opponents. From this point of view Ukraine has a paramount meaning for Europe in questions of security. Stability in Ukraine contributes to stability and safety in the whole region.

As for Russia, Ukraine is the most important country for it, in case of its losing "the West" will appear to be directly next to Russian confines. It serves as a protective "buffer" for Russia from the side of Europe. That's why some part of the Russian political elite interprets a rapprochement of Ukraine with the EU as a direct threat and even a "geopolitical provocation" to Russia from "the West". At the same time in Russian political discourse (the same as in pro-Russian parts of Ukraine) "the West" means, first of all, the United States, while Europe is the main "agent", by means of which the USA is promoting its interests on the territory of the former Soviet Union.

But the place for Ukraine is not inside the EU, but "nearby" or, more precisely - between the EU and the RF. In spite of all Ukrainian pro-European aspirations, even today the $\mathrm{EU}$ is following this position. 
According to Vozniak, the Russian "project of Ukraine" does not suppose just the absorption of Ukraine by Russia, as Russian imperialist revanchists see it. Russia regards Ukraine as a sphere of its interests and influences. It is trying to tie maximally Ukraine to the RF both in the sphere of economy and politics, and what is the main point, on the level of self-identification. For this purpose, Russia has effectively spread its own groups of influence on different levels and in diverse spheres - from mass media to the economy (Vozniak, 2002).

Followers of the pragmatic approach think that Ukraine could build its relations with the RF by itself, in compliance with its own interests. With certain, therefore, unreal circumstances, if both sides come to a real agreement, this project can be very effective. But both Russia and Ukraine should change themselves to make it possible. Russia, first of all, should refuse the imperial syndrome and look not for tactical, but far-sighted advantages with the condition of existing as a really friendly, not marionette state of Ukraine.

\section{The frame of European integration — as a civilizational choice}

The "European" theme became dominant in Ukrainian discourse mainly as a way to assert its distinctiveness from Russia. Ukraine's independence has been inherently linked to its assertion of its Europeanness. A "European" element of identity became for many Ukrainians an important part of the nation-building. They needed to identify themselves with "Europe" as a symbolic "center" in opposition to the "Russian world". From this perspective, Europeanness was seen as a marker of Ukrainian identity, and it underlines Ukraine's natural distinctiveness from Russia.

The main idea is that Ukraine is an organic part of Europe and European civilization, unnaturally separated from it by centuries of Russian rule. For national democrats in Ukraine, "returning to Europe" was perceived as a natural step, which implies a rejection of communism and the heritage of Russian domination for centuries. But in Russia (as well as for pro-Russian groups in Ukraine) it is also perceived as being a rejection of "Russia".

These ideas are shared by many pro-European supporters in Ukraine, as well as nationalist groups. According to such a vision - Russia has always been an Asiatic, despotically-expansionist and imperialist state which throughout history has attempted to deny Ukraine's self-determination, and moreover, to destroy Ukraine's very existence. Consequently, as claims Wilson (1997, p. 49), according to the nationalist view, Ukraine's primary foreign policy tasks should be to secure a "return to Europe" and build a strong independent state free from harmful Russian influence.

\section{INDEPENDENT UKRAINE/EUROPEAN UKRAINE}

There are debates around independent Ukraine and the idea of Ukraine as a European state. Although these two ideas do not go hand in hand, the fact is that the 
vision of Ukraine as a European country generally assumes Ukraine's right for independence. These two positions usually used similar discourses and arguments concerning European integration. Although the idea of an independent Ukraine and a European Ukraine are not the same, the idea of Ukraine as part of Europe is a central concept for the Ukrainian national idea (Wilson, 2009, p. 285). This view was taken also by many Ukrainian nationalists who perceive Ukraine as a European nation. According to this vision, Ukraine had values and culture similar to those of Europe before the Russian domination of Ukraine began. After many centuries of Ukrainian subordination to Russia, Ukraine's independence in 1991 was seen as an opportunity to "return to Europe".

The thesis that Ukrainians' historical ties to Europe distinguished them from Russians became a doctrinal statement in Ukrainian national ideology. According to this view, Ukrainians actually never considered their culture to be much different from the rest of Europe, since they shared the same Christian traditions and similar cultural roots - even during the periods when parts of Ukraine were in different empires or under different political regimes. There is a widespread view that Ukrainians are not looking for a road to Europe since they feel that they have always been there. This thesis about civilizational choice became one of the main beliefs for the followers of the exclusively European vision of Ukraine's future.

Civilizational choice - isn't an external, but inner one. I'm risking to seem banal and/or naive, but Ukraine's choice in favor of Europe, it seems to me, is final and cannot be subject to appeal. (Shcherba, 2010)

The civilizational discourse is about the transfer of values in a process of "education" and norms diffusion with the purpose of transforming neighbors. Europe is a valuable reference point in the Russia-Europe opposition, and for followers of the European way of Ukraine, Russia is situated on the opposite value pole. The followers of the Russian (or Eurasian) choice of development demonstrate exactly opposite arguments. In this case, through the unfolding antithesis of Russia-Europe, we can see a contra-position of Russia and Europe (the West) by a number of features, belonging to categories of values, policy and economy. For this position, there are obvious next points: the specifics of Russia - Russia has its own way (osobyj put) of development; rejections of alien values of the West; to emphasize the peaceful policy of Russia and the aggressive one of the West; the aspiration of the West to subdue territories of the former Soviet Union; and the strengthening of ties between Ukraine and Russia.

As Viktor Yushchenko claims:

All neighbors of Russia, trying to create some political systems, based on the principles of democracy, have very complicated relations with Moscow. Who's in charge of this? It's a problem of values. (Fakty, 2010b) 
We agree with Mykola Riabchuk, who claims that Huntington's thesis on civilizational affiliation "is deeply rooted in imperial stereotypes of Western European nations, which, historically, had accepted and adopted a Russian imperial view of Ukraine as a legitimate sphere of Russian influence, and still refuses to decouple it from Russia both culturally and politically". Riabchuk argues that the slogan "a return to Europe" seemingly constitutes for Ukrainian nation-builders a return to the norm, or a way to compensate for historical injustice, healing in the process "a developmental pathology" (Riabchuk, 2009, p. 20).

\footnotetext{
This romantic approach has caused Ukrainian activists to not only praise alleged Ukrainian "Europeanness" as opposed to Russian "Asianness", but to also accept the entire set of Western liberaldemocratic values as "natural" and "organic" for Ukrainians (yet allegedly "unnatural" for Russians). (Riabchuk, 2009, p. 23)
}

Opponents of the alliance of Ukraine with the EU very often say that the argument of civilizational closeness of Ukraine to Europe was brought to the public discourse because there is not a single rational submission to persuade Ukrainians that the country can hope for essential economic profits after its alliance with the EU.

The geographical justification has always gone hand-in-hand with historical claims for Europeanness. Ukraine's historical and geographical claims for a European identity have underpinned its demands for inclusion in contemporary Europe, marked by the borders of the EU. Ukrainians tend to see the EU as a civilization-based geopolitical entity. This perception of the EU was shared initially by most post-communist European countries (Wolczuk, 2008, pp. 89-90).

The boundaries are crucial for the construction of group identity. Borders offer a key advantage point for exploring the discourse of inclusion and exclusion. In this way, borders are spaces that foster and reproduce a sense of belonging to a particular community, but they are also sites of contestation and resistance to an imposed identity. In this sense the visa issues became an important topic in Ukrainian media discourse concerning relations with Europe.

\section{FRAME EUROPEAN INTEGRATION — AS AN INSTRUMENT OF INNER CHANGES}

In this frame, the alliance with the European Union is presented as a chance for the inner modernization of Ukraine. Also, this frame is often used in the topic of European integration for inner political struggle. Europe is perceived as an example, a reference point or a pole of attraction. The latter reduces Europe to a magnetic force, which involuntarily pulls others toward it.

Europeanization is framed as modernization. The most important challenge that lies ahead of Ukraine is the further transformation of Ukraine, strengthening democracy, solidarity and justice, thus creating a European society.

The idea of Europe as a civilizing force has gained value in official EU rhetoric. The growing focus on the EU's external activities has been followed by political 
rhetoric emphasizing Europe's obligation to act outside its own realm (Ifversen, 2007, p. 183). Civilization in this sense is not about material goods, but about the values that will change peoples' lives. The relations of civilizers with the civilized are set in an asymmetrical relation.

Integration into the European Union is framed as an instrument for further political and economic development. Here, Europe is mainly depicted as a standard (norm) setter. Joining the EU means joining the club with higher standards in political, social and economic spheres.

According to followers of the European choice, Eurointegration can help Ukraine to reform the state and to build a market economy, which is grounded on the basis of respect for private property and the supremacy of law. "Without an effective system of the state governing and reliable domestic policy, external policy - is it just a key from the broken door" (Hajdaj, 2010).

A thesis about "the necessity to extend Europe by the cost of Ukrainians who should create a Europe for themselves here, in Ukraine" (Shcherba, 2010) - also fits this frame. European integration should be "a good whip to make local authorities move" (Shcherba, 2010). Besides, many supporters of Euro-integration see the main, and even the only, hope for reforms in Ukraine from within. Strengthening of stability of the democratic political system and its institutions, modernization of the legal framework and providing transparency of the national legal system are the main political dividends for Ukraine from gradual European integration.

The European Union is a source of experience in the functioning of a market economy. Respectively, followers of Eurointegration present it as a way of modernizing the Ukrainian economy. According to this vision for Ukraine, European integration is a way of modernization of the financial system, overcoming technological backwardness, attracting foreign investments and the newest technologies, creating new work places, increasing the local commodity producer's competitiveness, access to World markets, and first of all, to the market of the EU.

"The European Union should be regarded as a school of effective, innovative economy, high social standards, developed democracy and effective management of social development. Euro-integration - is a direction on the implementation of European recipes of success on Ukrainian ground" (Gajduckyi, 2013).

The collaboration of Ukraine with the European Union is necessary for the technological renovation of Ukrainian industry. Without the modernization of its industry Ukraine won't be able to achieve stable economic development and to overcome growing backwardness from European countries.

Progress in approaching the EU can become a consolidating idea for Ukrainian society. "But it is impossible to reach immediate results in the European direction. Only those who clearly know what they want, who are ready to invest long-sighted efforts and honestly aspire to reach declared aims, will get success here" (Sushko, 2010).

In the frame of European integration as an instrument for inner changes or a chance for development, we can distinguish the sub-frame of Europe as a dream. 
For many in Ukraine, the European Union is still a dream. It means that the EU occupies the symbolic point of reference and attracts Ukrainians, but there is no clear vision of how to reach it. "Europe" is associated with something positive, decent, civilized and successful at the same time. Everyone would like to be a part of such a Europe. "The European idea or, if you wish, a dream, turned out to be that forbidden fruit, after which having tried, Ukrainians won't be able to dream about anything less" (Shcherba, 2010).

Europe is very often represented as a synonym of success and harmony in the pro-European Ukrainian discourse, but also as an unreachable ideal to which Ukrainians were aspiring for centuries. Such a vision of Europe, as of a dream, is typical for the romantic Ukrainian discourse. Opponents of the Eurointegrational choice of Ukraine are taking an image of Europe as a dream - as a counter-productive one. Moreover, this is an unrealizable and unrealistic dream.

A bird in hand is worth two in the bush, especially when it is not clear whether those two birds are healthy or not. [...] I mean the EU, burdened by a variety of inner problems. Ukraine has to look for its own way. (Segodnia, 2010)

\section{NEGATIVE FRAMES}

Negative frames typically represent Ukraine as a "dump" of Europe, a market of low-grade products, and a source of cheap natural resources and labor force. Such negative frames correlated with public perceptions of interests of the EU toward Ukraine, according to opinion polls. According to the Razumkov Centre (2010, p. 40), respondents suggest that the EU's interest in cooperating with Ukraine is pragmatic: "People think that the EU's interests focus on: Ukraine's natural resources; the Ukrainian market for EU goods; transit of energy resources; use of intellectual and scientific potential, manpower".

The topic of using Ukrainian territory to maintain ecologically dangerous waste from Europe is one of the negative frames, which presents negative consequences of rapprochement of Ukraine with the European Union. For example, one of the article's titles in Segodnia was: "They import shit to Ukraine, from which all Europe is dashing aside" (Segodnia, 2005b). The topic of importing industrial waste and dangerous substances disguised as raw materials from Europe is raised in this article, as well as a topic of mutual accusations between Ukraine and Russia of keeping dangerous wastes close to the border from both sides.

\section{EUROPE AS A FORTRESS — VISA ISSUES}

Visa issues and European visa policies are being widely debated in Ukrainian media and mainly represented as most problematic in Ukrainian-European relations. If other aspects of Ukraine-EU relations are characterized and presented by 
different frames, the representation of visa issues dominates the frame of closed Europe - as a fortress. Consequently, there is a typical metaphor of Europe as a fortress. Closely related to the metaphor of Europe as a fortress, is the metaphor of a closed door. In the dominant public perception in Ukraine, the doors of Europe are closed to admit newcomers, thus requiring them to knock constantly at the door while standing outside. In this sense, the visa restrictions and complications are an instrument to keep the door of Europe closed for Ukrainians.

Most of the publications on the visa issues in the analyzed Ukrainian press (particularly in Segodnia and Fakty), touched on mostly negative implications for Ukrainian citizens: refusals, restricted rules or negative experiences of Ukrainian applicants. Most of the press publication has been targeted against relevant EU policies and specific cases, rather than creating consistent pressure on Ukraine's government to succeed in related reforms. The newspapers Segodnia and Fakty usually used such characteristics as a border on the lock, the wall, to keep behind the fence, the consulate is inaccessible, etc.

Segodnia directly ties Euro-integration perspectives of Ukraine with internal processes in the EU. For instance, in the article "The EU: entrance is closed for Ukraine" (Segodnia, 2005a) the author does not tie European perspectives of Ukraine with its active actions as a subject, but transfers responsibility for that on the EU.

The key thesis, criticizing European aspirations of Ukraine, can be summarized by the following quotation from the newspaper Segodnia:

Neither Ukrainian power, nor European bureaucrats managed to explain clearly - is for what purpose Ukraine has to join the EU. What will ordinary Ukrainians get from this, what will be the consequences for these or those branches of the economy? Why, at the end, should we endow with our own independence and hang European bureaucrats over our neck? (Segodnia, 2005a)

After Yanukovych's coming to power the discourse of European perspectives obviously changed. The frame of the "pragmatic" approach began to dominate. Accordingly, metaphors of "partnership" occupied the main position in an official political discourse. "We'll be choosing pace and methods of European integration by ourselves, according to our national interests" - Viktor Yanukovych (Fakty, 2010a).

\section{CONCLUSIONS}

Europe becomes a powerful point of reference in Ukrainian public discussions. But Ukraine is uncertain about its future in/with Europe. Visions of Europe in Ukrainian political discourse are heterogeneous and ambivalent. The media in Ukraine reflect the diversity of opinions and perspectives, differences in vision of the direction of a developing country, as well as "the fluidity of collective identity categories, as they change in response to changing power structures, institutional realign- 
ments, and adaptation of values" (Dyczok, 2009, p. 386). The Ukrainian media also reflect a range of changes and ongoing conflicts in building national identity in Ukraine, and the continued ambiguity of this process.

In the frame of geopolitical confrontation the European aspirations of Ukraine are determined by the geopolitical struggle between the "West" and Russia, where Ukraine appears as "a buffer zone". In this frame the independence of Ukraine is tied directly to its release from Russian influence. But also in the frame of European integration as a civilizational choice - the "European" theme became dominant in Ukrainian public discourse mainly as a way to assert its distinctiveness from Russia. From this perspective, Europeanness was seen as a marker of Ukrainian identity, and underlines Ukraine's "organic" belonging to Europe. In the frame of European integration as an instrument of inner changes, cooperation with the EU is presented as a chance for the inner modernization of Ukraine. Joining the EU means joining a club with higher standards in the political, social and economic spheres. For Ukraine it is a way of modernizing the economy, overcoming technological backwardness, strengthening democracy, and rules of law.

The images of doors being closed and safeguarded evoked an interpretation of Europe as a fortress. In this context the metaphor of doors - widely used in different frames - also has the potential to be positive (if opened) and negative (if closed). In the dominant Ukrainian perception - European doors are rarely closed to admit newcomers, thus requiring them to constantly knock at the door while standing outside. In sum, the metaphor of closed door shows that Ukraine is located outside the European Union.

\section{Acknowledgements}

This article is based on the results of the author's PhD research "The media and political discourse in post-communist Ukraine" defended on 18th March 2016 at the University of Wrocław, Poland. The project was funded by the National Science Centre of Poland on the basis of Decision Nr UMO-2011/01/N/HS5/04002.

\section{REFERENCES}

Ambrosio, T. (2009). Authoritarian Backlash: Russian Resistance to Democratization in the Former Soviet Union. Farnham: Ashgate.

BBC. (2006, October 31). The press in Ukraine. Retrieved April 24, 2016 from http://news.bbc.co. uk/2/hi/europe/4073375.stm.

De Fina, A., Schiffrin, D., Bamberg, M. (eds.). (2006). Discourse and Identity. Cambridge: Cambridge University Press.

Dyczok, M. (2009). Ukraine's changing communicative space destination Europe or the Soviet past? In: Zaleska-Onyshkevych, L., Rewakowicz M. (eds.). Contemporary Ukraine on the Cultural Map of Europe. New York: M.E. Sharpe Inc.

Entman, R.M. (1993). Framing: Toward clarification of a fractured paradigm. Journal of Communication, 43 (4), pp. 51-58.

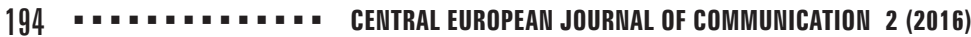

Central European Journal of Communication vol. 9, no 2 (17), Fall 2016

(C) for this edition by CNS 
Entman, R.M. (2003). Cascading activation: Contesting the White House's frame after 9/11. Political Communication, 20, pp. 415-423.

Fakty. (2010a, October 8). Viktor Yanukovich: "Processy evrointegracii Ukrainy otvechayut stremleniyam Evropy preodolet posledstviya krizisa I postroit dejstvitelno edinoe ekonomicheskoe prostranstvo" [Viktor Yanukovich. "The process of European integration of Ukraine meet the aspirations of Europe to overcome the crisis and build a truly common economic space"]. Retrieved May 12, 2012 from http://fakty.ua/120283-viktor-yanukovich-processy-evrointegracii-ukrainyotvechayut-stremleniyam-evropy-preodolet-posledstviya-krizisa-i-postroit-dejstvitelno-edinoe-ekonomicheskoe-prostranstvo.

Fakty. (2010b, January 13). Viktor Yucshenko: "S Rossiej my dolzhny govorit o sozdanii effektivnyh druzheskih otnoshenij no pri etom ne torgovat nezavisimostyu i suverenitetom" [Viktor Yushchenko: "With Russia we have to speak about the creation of efficient friendly relations, but do not sell independence and sovereignty"]. Retrieved April 11, 2012 from http://fakty.ua/10130viktor-yucshenko-s-rossiej-my-dolzhny-govorit-o-sozdanii-effektivnyh-druzheskih-otnoshenij-no-pri-etom-ne-torgovat-nezavisimostyu-i-suverenitetom.

Fakty. (2010c, October 28). Vybor Kieva - Evrosoyuz ili Rossia? [Choice of Kiev - European Union or Russia]. Retrieved May 12, 2012 from http://fakty.ua/121589-vybor-kieva-evrosoyuz-ili-rossiya.

Gajduckyi, P. (2013). Ukraina-ES: problem integracii [Ukraine — The EU: Problems of integration]. Zerkalo Nedeli, 20 (7 June). Retrieved January 18, 2014 from http:/gazeta.zn.ua/international/ ukraina-es-problemy-integracii-_.html.

Gamson, W.A. (1989). News as framing: Comments on Graber. The American Behavioral Scientist, 33 (2), pp. 157-161.

Hajdaj, V. (2010). Spasti Prezidenta Yanukovicha [To save President Yanukovich]. Zerkalo Nedeli, 8 (27 February). Retrieved January 13, 2013 from http://zn.ua/articles/59375.

Ifversen, J. (2007). It's about time: Is Europe old or new? In: Mole, R. (ed.). Discursive Constructions of Identity in European Politics. Basingstoke: Palgrave Macmillan.

Ivanov, V., Kotyuzhyns'ka, A., Ermolenko, V. (eds.). (2011). Ukrainskyj media-landshaft [Ukrainian Media-Landscape]. Kyiv: K. Adenauer Fund in Ukraine, pp. 170-190.

Kapitonenko, M., Shamshur, O., Chalyi, V. (2012). Ukraine and EU: Challenges that Loom Ahead. The German Marshall Fund, Washington, DC. Retrieved May 14, 2013 from http://www.gmfus. org/wpcontent/blogs.dir/1/files_mf/kapitonenkoetal_ukraineeu_feb12.pdf.

Kulyk, V. (2010). Dyskurs ukrains'kykh medii: identychnosti, ideolohii, vladni stosunku [The Ukrainian Media Discourse: Identities, Ideologies, Power Relations]. Kyiv: Krytyka.

Kulyk, V. (2011). The media, history and identity: Competing narratives of the past in the Ukrainian popular press. National Identities, 13, pp. 287-303.

Laclau, E., Mouffe, C. (1985). Hegemony and Socialist Strategy. London: Verso Press.

Litvinenko, A. (2010). Kakuyu model vneblokovosti my vybiraem [Which model of non-alliance do we choose?]. Zerkalo Nedeli, 12 (27 March). Retrieved January 13, 2012 from http://zn.ua/articles/59637.

Razumkov Centre. (2010). National Security \& Defence, 2. Kyiv.

Riabchuk, M. (2009). Cultural fault lines and political divisions. In: Zaleska-Onyshkevych, L., Rewakowicz, M. (eds.). Contemporary Ukraine on the Cultural Map of Europe. New York: M.E. Sharpe Inc.

Segodnia. (2005, June 8). ES: Ukraine vhod zakryt. Segodnia, 127 (2069). Retrieved May 11, 2012 from http://www.segodnya.ua/oldarchive/c2256713004f33f5c2257019004fc182.html.

Segodnia. (2005, November 10). V Ukrainu importiruyut der`mo, ot kotorogo sharachaetsya Evropa [They import shit to Ukraine, from which all Europe is dashing aside]. Segodnia, 256 (2198). Retrieved March 12, 2010 from http://www.segodnya.ua/oldarchive/c2256713004f33f5c2257 0b400595365.html. 


\section{Oleksii Polegkyi}

Segodnia. (2010, October 4). Ukraina idet v ES kak v anecdote [Ukraine is going in the EU as in the joke]. Retrieved May 11, 2012 from http://www.segodnya.ua/specprojects/transcripts/nardepot-kpu-alekceev-ukraina-idet-v-ec-kak-v-anekdote.html.

Segodnia. (2012, March 25). Ukraina ne nuzhna Evrope [Europe does not need Ukraine]. Retrieved April 12, 2013 from http://www.segodnya.ua/politics/power/ukraina-ne-nuzhna-evrope$\% \mathrm{E} 2 \% 80 \% 93$-medvedchuk.html.

Shcherba, A. (2010). Kto dast otvet na "ukrainskij vopros? [Who will answer "the Ukrainian question”?]. Zerkalo Nedeli, 19. Retrieved January 13, 2012 from http://gazeta.zn.ua/POLITICS/ kto_dast_otvet_na_ukrainskiy_vopros.html.

Sushko, A. (2010). Ukraina-ES: strategicheskij kurs ili fasadnaya integracyya? [Ukraine-EU: Strategic course or facade integration?]. Zerkalo Nedeli, 23 (19 June). Retrieved January 13, 2013 from http://zn.ua/articles/60485.

Tankard, J. (2001). The empirical approach to the study of media framing. In: Reese, S., Gandy, O., Mahwah, G.E. (eds.). Framing Public Life: Perspectives on Media and Our Understanding of the Social World. NJ: Lawrence Erlbaum Associates.

Telekritika. (2012, February 28). Gazeta "Segodnia" obignala "Fakty" za okhoplennyam audytorii. Retrieved May 11, 2012 from http://www.telekritika.ua/news/2012-02-28/69956.

Van Dijk, T. (2001). Critical discourse analysis. In: Schiffrin, D., Tannen, D., Hamilton, H. (eds.). The Handbook of Discourse Analysis. Oxford: Blackwell Publishers, pp. 352-371.

Van Gorp, B. (2007). The constructionist approach to framing: Bringing culture back. Journal of Communication, 57, pp. 60-78.

Vozniak, T. (2002). Project Ukraine. Results of decade, 11 August. Retrieved May 22, 2014 from http:// www.regnum.ru/news/46970.html\#ixzz3CkDSkR9R.

Wilson, A. (1997). Ukrainian Nationalism in the 1990s, a Minority Faith. Cambridge, Massachusetts: Cambridge University Press.

Wilson, A. (2009). The Ukrainians: Unexpected Nation. Yale: Yale University Press.

Wolczuk, K. (2008). Ukraine and its relations with the EU in the context of the European Neighbourhood Policy. In: Fischer, S. (ed.). Ukraine: Quo Vadis? Chaillot Paper, No. 108, EU Institute for Security Studies.

Zolkina, M. (2013). European integration of Ukraine: Experience of yesterday for development of tomorrow. Ilko Kucheriv Democratic Initiatives Foundation, Public Opinion, No. 13. 